\title{
PHYSIOLOGICAL RESPONSES OF UPLAND RICE; WATER AND NITROGEN UPTAKES AND WATER USE EFFICIENCY UNDER WET AND PARTIAL DRYING SOIL CONDITIONS
}

\author{
KITILU, Mganga Joshua Fimbo ${ }^{1}$ (1) \\ ${ }^{1}$ Tanzania Agriculture Research Institute (TARI), Graduate School of Agriculture, Faculty of Agriculture Yamaguchi Uni- \\ versity, Japan
}

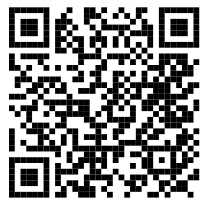

versity, Japan

Received 6 June 2021

Accepted 18 June 2021

Published 30 June 2021

Corresponding Author

KITILU, Mganga Joshua Fimbo, kiti

luj@yahoo.com

DOI 10.29121/

granthaalayah.v9.i6.2021.3914

Funding: This research received no specific grant from any funding agency in the public, commercial, or not-for-profit sectors.

Copyright: (C) 2021 The Author(s). This is an open access article distributed under the terms of the Creative Commons Attribution License, which permits unrestricted use, distribution, and reproduction in any medium, provided the original author and source are credited.

\section{ABSTRACT}

Rice is an important cereal and staple food crop in Tanzania, the rice production has not met the demand, mainly due to water shortage. Dissemination of New Rice for Africa (NERICA) has been in progress to improve production in upland rice ecosystem. A pot experiment was conducted in a split plot design at Yamaguchi university farm to elucidate water uptake, water use efficiency and nitrogen uptakes for two NERICA cultivars (NERICA1 and 2) and two Japanese rice cultivars (Yumenohatamochi and Hinohikari). Amount of transpired water was recorded every day until maturity. Nitrogen uptake at booting and maturity growth stage were compared between these cultivars. The results indicated that amount of water transpired was greater for NERICA cultivars in the period from booting to maturity, in particular, under the dry soil condition. All the cultivars showed similar slope of regression lines between amount of transpired water and dry matter production (Water use efficiency), Nitrogen concentration per unit weight was higher in NERICA rice than in Japanese rice during grain filling stage. These results indicate that NERICA's rice cultivars have high productivity due to higher water and Nitrogen uptake during grain filling stage compared with the Japanese rice cultivars tested.

Keywords: NERICA, Nitrogen Uptake, Upland Rice, Water Uptake, Water Use Efficiency

\section{INTRODUCTION}

Agriculture is an important sector for social-economic development in Tanzania "National Rice Development Strategy" (2009), and have been the major source of staple food production and source of income for the poor small householder farmers in the marginalized area of the country. On the other hand, Agricultural sector has remained susceptible to climate change and variability within and between the 
seasons Rowhani et al. (2011). Water deficit is among the major abiotic factors affecting rice yields under rainfed ecosystems in Tanzania. Moderate moisture stresses during vegetative growth phases reported to cause grain yield losses of between $26-46 \%$ in rainfed rice cultivation and during moisture stress imposed at reproductive growth phases losses of between $58-79 \%$ or more than $50 \%$ KITILU et al. (2019), Sikuku et al. (2012), Tahmasebi et al. (2008) was reported under rainfed rice cultivation. However, Varieties that produce more grain under moisture deficit are said to posses' high adaptability for drought tolerance KITILU et al. (2019).

The effort to increase rainfed rice production in Tanzania, was initiated by the Rice research program from 2009 whereby they started to release some of cultivars for NERICA (New Rice for Africa) for farmers' production. These NERICA cultivars reported to have the characteristics like early maturity "Consortium Formed To Rapidly Disseminate New Rice For Africa" (2000), high weed competition "The Rice Challenge In Africa" (2004) and good yield production in drought prone and infertile land KITILU et al. (2019), Oikeh et al. (2008). The combination of Water and nutrient uptake capacity of a plant plays a great role on its adaptability to grow in different ecosystems, Matsunami et al. (2010), Matsunami et al. (2009) compared yield production among NERICA and Japanese cultivars in flooded and rainfed upland conditions with high and low soil nitrogen levels. The findings indicated that NERICA cultivars had a higher ability to absorb Nitrogen than Japanese cultivars. The characteristics was pronounced in the rainfed upland that had enough water condition. Therefore, NERICA's may achieve high dry matter production under upland and in $\mathrm{N}$-limited conditions through maintaining preferable plant nutrition in such conditions. These studies have not yet elucidated fully the physiological characters behind NERICA's performance under water limited conditions. The information of NERICAs cultivar's ability to uptake water and nutrient Nitrogen as affected by water regimes in long-term is limited. In addition, the information that reveals the characteristics of NERICAs on water and nitrogen uptake, under deficits of water is missing.

In this study it was assumed two aspects; i) NERICA cultivars show high dry matter production in grain filling stages due to high gas exchange rate in leaves, and ii) the high Nitrogen uptakes may be correlated to water uptake during the grain filling stages. The study elucidated daily water uptake up to maturity under wet and dry soil conditions.

\section{MATERIALS AND METHODS}

\section{Experimental environments}

The experiment was carried out in a vinyl house at Yamaguchi University. Two NERICA cultivars (NERICA1 and NERICA2), one Japanese upland rice cultivar (Yumenohatamochi) and one Japanese lowland rice cultivar (Hinohikari) were grown in 1/5000a Wagner pots each of which was filled with $2.5 \mathrm{~kg}$ of soil. The soil was commercial soil (Naekko, MC FERTICOM. CO., Ltd.) that consisted of artificially 
aggregated particles in a diameter of around $2.0 \mathrm{~mm}$. Fertilizers were mixed with the soil at rate of $0.5 \mathrm{~g} \mathrm{~N}, 0.5 \mathrm{~g} \mathrm{P}_{2} \mathrm{O}_{5}$ and $0.5 \mathrm{~g} \mathrm{~K}_{2} \mathrm{O}$ per $1 \mathrm{~kg}$ of soil. Soil $\mathrm{pH}$ before sowing was 5.4

\section{Experimental design}

The pots were arranged in a split plot design with five replicate blocks, in which the main plot and sub-plot were soil water regime and cultivar, respectively. In the sub-plots, five pots were prepared for all the cultivars for sampling at four different growth stages. One of the five pots was spare. The soil water regime consisted of wet and dry treatments. The water regimes were controlled as below.

\section{Cultural details}

Before sowing, the soil in each pot was irrigated with one litter of tap water. Seeds were peregrinated in tap water at $25^{\circ} \mathrm{C}$ for 24 hours. Six to seven seeds were sown in each pot. After establishment, the seedlings were thinned to two in each pot. At thirty days after sowing, a nutrient solution of $0.4 \mathrm{~g} \mathrm{P}_{2} \mathrm{O}_{5}, 0.32 \mathrm{~g} \mathrm{~K}_{2} \mathrm{O}, 49.4 \mathrm{~g} \mathrm{MgSO}_{4}$, $0.901 \mathrm{~g} \mathrm{MnCl}_{2} 4 \mathrm{H}_{2} \mathrm{O}, 1.430 \mathrm{~g} \mathrm{H}_{3} \mathrm{BO}_{3}, 0.110 \mathrm{~g} \mathrm{ZnSO}_{4} 7 \mathrm{H}_{2} \mathrm{O}, 0.040 \mathrm{~g} \mathrm{CuSO}_{4} 5 \mathrm{H}_{2} \mathrm{O}, 0.019 \mathrm{~g}$ $\left(\mathrm{NH}_{4}\right)_{6}\left(\mathrm{MO}_{7} \mathrm{O}_{2}\right) 44 \mathrm{H}_{2} \mathrm{O}$ and $11.31 \mathrm{~g} / 0.5 \mathrm{~L}$ Fe (III) EDTA were applied in each pot.

For controlling soil water regimes, water loss by evapotranspiration was weighed, and replaced with irrigated water. The pot weights at $80 \%$ and $60 \%$ of saturated soil were initially determined for the wet and dry treatments, respectively, before the control of water regime. One pot out of the five replicate pots was weighed in each sub-plot to estimate the water loss, and then replace the loss with tap water as applied it from the soil surface. The other pots in the sub-plot were applied with the same weight of water as above. The work was conducted in every two days when the seedlings were small and once in a day as the seedlings grew. When transpiration was very high, pots weighted once a day, but $100-150 \mathrm{ml}$ of water applied several times in a day without weighing the pots to prevent from heavy drying of soil. Top part of pots and soil surface covered with well-designed silver sheets to reduce surface evaporation and rise of soil temperature (Figure 1 ).

\section{Measurements}

Temperature and relative humidity of the ambient air were monitored with thermo recorders (TR-72S, T\&D, Japan) throughout the growing period (Table 1 ). Amount of water loss from each pot was measured gravimetrically. Total weight of water applied was recorded from each pot. Three blank pots without plants were also prepared in each water regime. Amount of water loss from each blank pot was also measured, and soil evaporation was estimated by averaging weight of water evaporated from the three blank pots. Total amount of transpired water from each pot (Tr) was then calculated by subtracting the estimated evaporation from the amount of water loss from each pot. To eliminate an effect of humidity on transpiration, Tr was divided with daytime vapor pressure deficits (VPD) in the ambient air determined between 1 hour after dawn and one hour after sunset.

Sampling of shoots and roots was conducted at 40 days after sowing, at booting stage, at 2 weeks after heading stage and at maturity stage. All the leaves were 
removed from straws and their areas were measured with an automatic area meter (AAM-8, Hayashi Denko, Tokyo). Then, roots were roughly separated from the soils by sieving them on $2.0 \mathrm{~mm}$ mesh. The remaining soils on the roots were gently washed with tap water. All the plant materials were dried at $105^{\circ} \mathrm{C}$ for 30 minutes and dried at $70^{\circ} \mathrm{C}$ for three days. The dried samples were weighed to obtain dry weights. Root samples were completely burnt at $600^{\circ} \mathrm{C}$ for 30 minutes to determine the weight of soil adhering to the roots. The weight of soil particles was subtracted from the weights of oven-dried roots.

Water use efficiency (WUE) defined as a ratio of dry matter produced per unit of transpired water was estimated by graph figure using equation (1) used by (Kitilu, 2011) KOBATA et al. (1996) as indicated below;

WUE $=$ TDW $/(\mathrm{Tr} / \mathrm{VPD})(1)$

Where by, TDW and Tr/VPD indicate total dry weight of plant and total transpired water divided by VPD, respectively.

Nitrogen concentrations (g N g-1 DW) of shoot parts were measured with the Kjeldahl method. Leaf lamina, straw (leaf sheaths and stem) and grains were grounded by a milling machine. The grounded tissues at weight of $0.5 \mathrm{~g}$ were completely digested with a mixture solution of $\mathrm{H}_{2} \mathrm{SO}_{4}$ and Hydrogen peroxide at $300^{\circ} \mathrm{C}$ for about 2 hours. The digested solution was diluted with water to obtain $100 \mathrm{ml}$ solution. Ten $\mathrm{ml}$ of the diluted solution was mixed with adequate volume of $10 \mathrm{~N} \mathrm{NaOH}$, and distilled $\mathrm{NH}_{3}$ was trapped within $2 \%$ Boric acid using an automatic distillation machine (UDK 132, VELP Scientifica, Italy). Moles of the distilled $\mathrm{NH}_{3}$ were determined by titration with $0.01 \mathrm{M} \mathrm{H}_{2} \mathrm{SO}_{4}$. Then, the $\mathrm{N}$ concentration of samples was calculated. Total $\mathrm{N}$ content per pot was also calculated with the dry weight and the $\mathrm{N}$ concentrations of the tissues.

\section{Statistical Analysis}

The data obtained in the experiment were subjected to analysis of variance (ANOVA). And they were analyzed for the arrangement of split-split plot design. Mean comparison (multiple range tests) was done with a Tukey-Kramer's honestly significant deference at $\mathrm{P}<0.05$.

\section{RESULTS}

Table 1 Monthly average of daytime temperature $\left({ }^{\circ} \mathrm{C}\right)$, relative humidity $(\mathrm{RH})$ and vapor pressure deficits (VPD) ${ }^{a}$ during the daytime in growing environment (vinyl house

\begin{tabular}{cccccc}
\hline Months & $\begin{array}{c}\text { Average } \\
\text { Temperature } \\
\left({ }^{\circ} \mathbf{C}\right)\end{array}$ & Max T $\left({ }^{\circ} \mathbf{C}\right)$ & Min T $\left({ }^{\circ} \mathbf{C}\right)$ & RH (\%) & $\begin{array}{c}\text { Average VPD } \\
\text { (KPa) }\end{array}$ \\
\hline June & 31.5 & 37.9 & 24.0 & 57.5 & 2.19 \\
July & 33.6 & 39.6 & 25.9 & 62.7 & 2.11 \\
August & 36.9 & 40.4 & 28.1 & 53.7 & 2.99 \\
\hline
\end{tabular}




\begin{tabular}{|c|c|c|c|c|c|}
\hline \multicolumn{6}{|c|}{ Table 1 continued } \\
\hline $\begin{array}{l}\text { Septem- } \\
\text { ber }\end{array}$ & 33.1 & 39.3 & 23.3 & 51.9 & 2.56 \\
\hline October & 26.4 & 30.9 & 19.6 & 57.2 & 1.55 \\
\hline
\end{tabular}

a: The daytime VPD were determined between 1 hour after dawn and sunset.

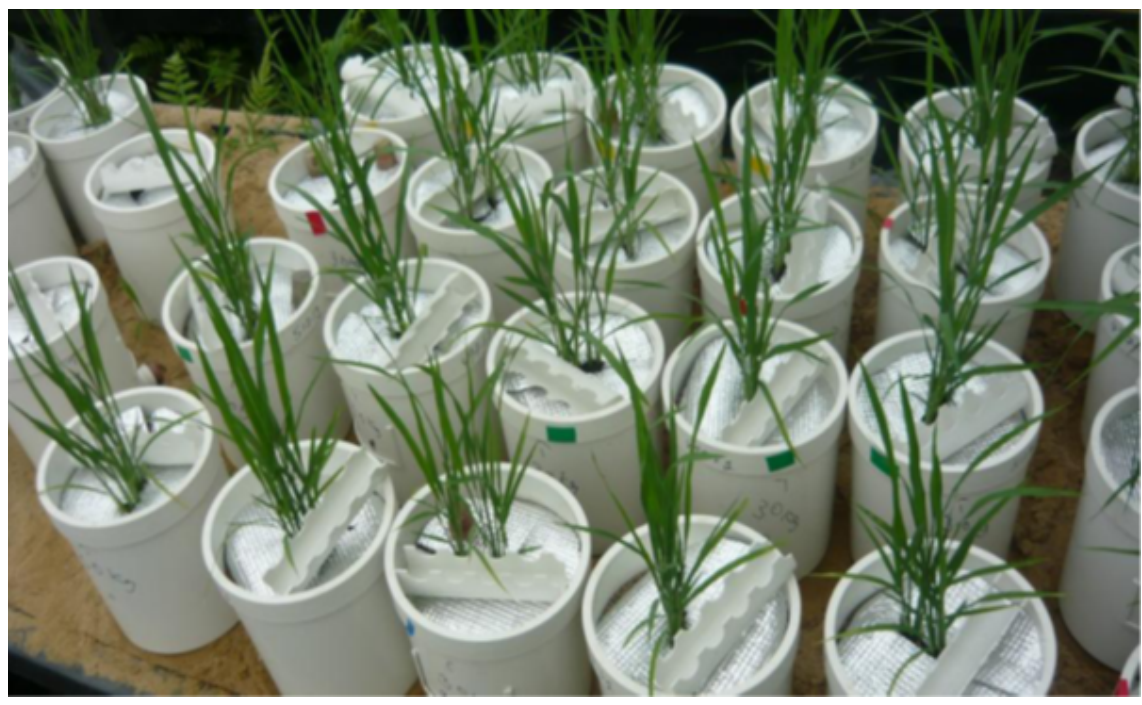

Figure 1 Soil surface of the pots were covered with a designedsilvery sheet to reduce evaporation from it.

\section{Phenological characters}

hows periods from sowing to heading stage, 2 weeks after heading stage and maturity stage of four cultivars in the experiment. The periods from sowing to heading stage were longer in the dry treatment than in the wet treatment. In the wet treatment, the period to heading stage was longer for Japanese cultivars than NERICA cultivars. The period of NERICA 1, NERICA 2 and Hinohikari were prolonged by soil dryness for 8-10 days, while it was further prolonged for 14 days in Yumenohatamochi.

The periods from sowing to maturity were also longer in the dry treatment than in the wet treatment. In the wet treatments, duration of grain filling of the cultivars, which is the days from heading to maturity, was 42, 39, 32 and 38 days for NERICA1, NERICA2, Yumenohatamochi and Hinohikari respectively. In the dry treatment, the duration of grain filling was 40,37, 28 and 32, respectively. The duration of grain filling was shorter in Japanese cultivars than the NERICA cultivars.

Table 2 Days after sowing to heading stage, 2 weeks after heading stage (2WAH) and maturity stage in 2 NERICA cultivars and 2 Japanese rice cultivars

\begin{tabular}{clccc}
\hline Water regime & Cultivars & Heading (DAS) & 2WAH & Maturity (DAS) \\
Wet $\mathbf{( 8 0 \% )}$ & NERICA1 & 71 & 85 & 113 \\
\hline
\end{tabular}




\begin{tabular}{ccccc}
\hline & \multicolumn{4}{c}{ Table 2 continued } \\
\hline & NERICA 2 & 68 & 83 & 107 \\
\hline & Yumenohatamochi & 87 & 101 & 119 \\
\hline \multirow{2}{*}{ Dry (60\%) } & Hinohikari & 97 & 111 & 135 \\
& NERICA 1 & 79 & 93 & 119 \\
& NERICA 2 & 78 & 92 & 115 \\
& Yumenohatamochi & 101 & 115 & 129 \\
\hline
\end{tabular}

NB. In the Wet and Dry treatments, relative soil content (weight of water contained in the soil per weight of water at the soil saturated) was adjusted to $80 \%$ and $60 \%$, respectively, at irrigation. DAS and 2 WAH indicates Days after sowing and 2 weeks after heading respectively.

\section{Dry weights and leaf area development}

The shoot dry weight was significantly reduced by the dry treatment for all cultivars (Table 3 ), except NERICA 1 at 40 days after sowing. In the wet treatment, the shoot dry weights were heavier in Japanese cultivars than those of the NERICA cultivars at booting and 2 weeks after heading stages. The NERICA cultivars apparently increased the shoot dry weight from 2 weeks after heading to maturity stages, while Japanese cultivars showed little increase during the period. At maturity, there was no difference in the shoot dry weights among the cultivars. In the dry treatment, at 40 days after sowing, NERICA1 showed significantly greater dry weights than the other cultivars. Japanese cultivars became heavier at booting stage. At 2 weeks after heading and maturituy stages, no significant difference was found among cultivars.

The root dry weigth was also reduced by the soil dryness, in particular, during growth stages before 2 weeks after heading stage (Table 3 ). However, at maturity, the root dry weights in the dry treatment became comparable to those in the wet treatment. In the wet treatment, the root dry weights of Hinohikari tended to be greater than those of the NERICA cultivars and Yumenohatamochi until booting stages. The root dry weights of the NERICA cultivars greatly increased from 2 weeks after heading stages and afterward, while the root dry weights of Japanese cultivars did not show such great increase as found in NERICA cultivars. In the dry treatment, increase in the root dry weight was almost same as in the wet treatment.

Table 3 Dry weights of the four rice cultivars at 40 days after sowing (40DAS), booting, 2 weeks after heading (2WAH) and maturity

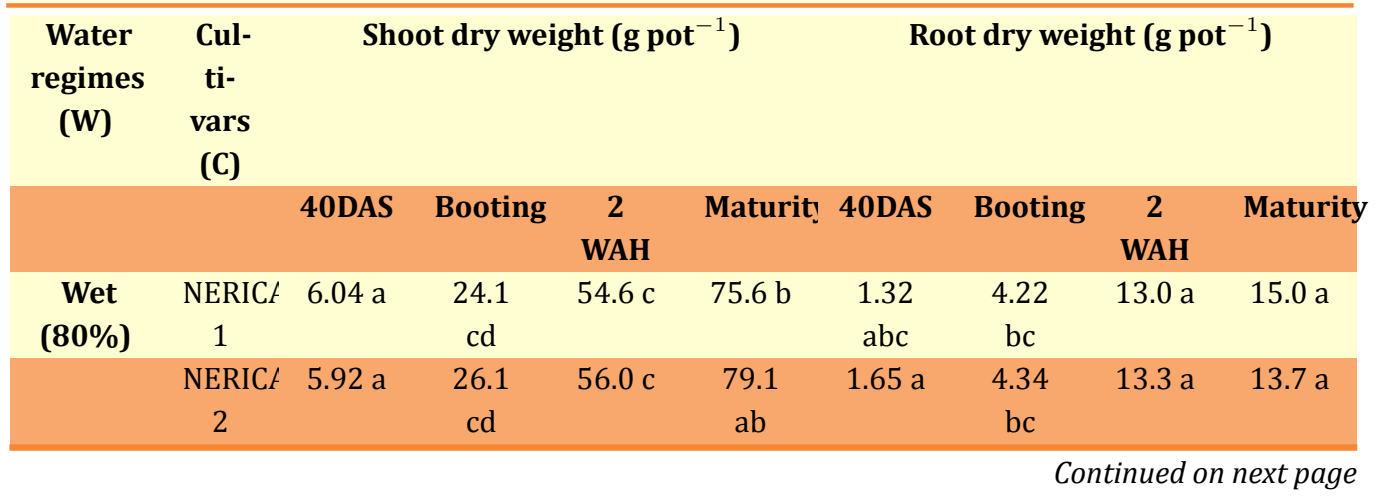




\begin{tabular}{|c|c|c|c|c|c|c|c|c|c|}
\hline \multicolumn{10}{|c|}{ Table 3 continued } \\
\hline & Yume $^{a}$ & $6.13 \mathrm{a}$ & $35.6 \mathrm{~b}$ & $72.7 \mathrm{~b}$ & $71.9 \mathrm{~b}$ & $\begin{array}{c}1.55 \\
a b\end{array}$ & $5.77 \mathrm{~b}$ & $\begin{array}{c}10.1 \\
\mathrm{ab}\end{array}$ & $\begin{array}{c}10.9 \\
\mathrm{ab}\end{array}$ \\
\hline & Hinohil & $5.68 \mathrm{a}$ & 55.9 a & $85.3 \mathrm{a}$ & 89.4 a & $\begin{array}{l}1.25 \\
a b c\end{array}$ & $\begin{array}{c}11.47 \\
\mathrm{a}\end{array}$ & $\begin{array}{c}12.1 \\
\mathrm{ab}\end{array}$ & $14.4 \mathrm{a}$ \\
\hline \multirow[t]{4}{*}{$\begin{array}{c}\text { Dry } \\
(60 \%)\end{array}$} & $\begin{array}{c}\text { NERIC } t \\
1\end{array}$ & $4.90 \mathrm{a}$ & $11.9 \mathrm{e}$ & $53.5 \mathrm{c}$ & $51.7 c$ & $\begin{array}{c}0.70 \\
\mathrm{~cd}\end{array}$ & $2.75 \mathrm{c}$ & $\begin{array}{c}10.2 \\
\mathrm{ab}\end{array}$ & $\begin{array}{c}13.2 \\
\mathrm{ab}\end{array}$ \\
\hline & $\begin{array}{c}\text { NERICF } \\
2\end{array}$ & $2.44 \mathrm{~b}$ & $14.1 \mathrm{e}$ & $56.8 \mathrm{c}$ & $52.9 \mathrm{c}$ & $\begin{array}{l}1.01 \\
\text { bcd }\end{array}$ & $2.83 \mathrm{c}$ & $\begin{array}{c}7.56 \\
\mathrm{ab}\end{array}$ & $\begin{array}{c}12.4 \\
\mathrm{ab}\end{array}$ \\
\hline & Yume $^{a}$ & $2.54 \mathrm{~b}$ & $\begin{array}{c}18.6 \\
\text { de }\end{array}$ & $59.1 \mathrm{c}$ & $52.8 \mathrm{c}$ & $\begin{array}{c}0.94 \\
\mathrm{~cd}\end{array}$ & $3.63 \mathrm{c}$ & $5.78 \mathrm{~b}$ & $\begin{array}{c}13.0 \\
a b\end{array}$ \\
\hline & Hinohil & $2.41 \mathrm{~b}$ & $\begin{array}{c}30.1 \\
b c\end{array}$ & $53.8 \mathrm{c}$ & $56.7 \mathrm{c}$ & $0.67 \mathrm{~d}$ & $6.32 \mathrm{~b}$ & $\begin{array}{c}8.57 \\
a b\end{array}$ & $\begin{array}{c}12.8 \\
\mathrm{ab}\end{array}$ \\
\hline \multirow[t]{3}{*}{ ANOVA } & W & $* *$ & $* *$ & $* *$ & $* *$ & $* *$ & $* *$ & NS & NS \\
\hline & $\mathrm{C}$ & ** & ** & $* *$ & $* *$ & NS & ** & $* *$ & NS \\
\hline & $\begin{array}{c}\mathrm{W} \times \\
\mathrm{C}\end{array}$ & $* *$ & $* *$ & $* *$ & NS & $* *$ & $* *$ & $* *$ & $* *$ \\
\hline
\end{tabular}

Yume $^{a}=$ Yumenohatamochi, * and ${ }^{* *}$ indicate significant at 5\% and 1\% level, respectively, by ANOVA. NS indicates not significant.

Leaf areas per pot were significantly reduced by the dry treatment except at 2 weeks after heading stage (Table 4 ). In the wet treatment, there were no significant differences among cultivars in the leaf area at 40 days after sowing. The leaf area in Yumenohatamochi and Hinohikari were significant lager than those in NERICA cultivars at booting stage. The leaf area in NERICA cultivars increased during booting stage to 2 weeks after heading stage, while those in Japanese cultivars slightly decreased. As a result, there were no differences in leaf area among cultivars at 2 weeks after heading stages. In the dry treatment, changes in the leaf area of the cultivars were almost similar to those in the wet treatment.

Table 4 Effects of water regemes on Leaf area development

\begin{tabular}{|c|c|c|c|c|}
\hline \multirow[t]{2}{*}{ Water regemes (W) } & \multirow[t]{2}{*}{ Cultivars (C) } & \multicolumn{3}{|c|}{ Leaf area $\left(\mathrm{m}^{2}\right.$ pot $\left.^{-1}\right)$} \\
\hline & & 40DAS & Booting & 2WAH \\
\hline \multirow[t]{4}{*}{ Wet $(80 \%)$} & NERICA1 & $0.08 \mathrm{a}$ & $0.24 b$ & $0.30 \mathrm{ab}$ \\
\hline & NERICA2 & $0.07 a$ & $0.22 b c$ & $0.27 \mathrm{ab}$ \\
\hline & Yume $^{a}$ & $0.09 a$ & $0.36 \mathrm{a}$ & $0.24 \mathrm{~b}$ \\
\hline & Hinohikari & $0.08 \mathrm{a}$ & $0.34 \mathrm{a}$ & $0.30 \mathrm{ab}$ \\
\hline \multirow[t]{4}{*}{ Dry (60\%) } & NERICA1 & $0.03 \mathrm{~b}$ & $0.11 \mathrm{~d}$ & $0.30 \mathrm{ab}$ \\
\hline & NERICA2 & $0.03 \mathrm{~b}$ & $0.15 \mathrm{~cd}$ & $0.32 \mathrm{a}$ \\
\hline & Yume $^{a}$ & $0.02 b$ & $0.21 b c$ & $0.24 b$ \\
\hline & Hinohikari & $0.03 \mathrm{~b}$ & $0.22 \mathrm{bc}$ & $0.27 \mathrm{ab}$ \\
\hline \multirow[t]{3}{*}{ ANOVA } & W & $* *$ & $* *$ & NS \\
\hline & $\mathrm{C}$ & NS & $* *$ & $* *$ \\
\hline & $\mathrm{W} \times \mathrm{C}$ & NS & NS & NS \\
\hline
\end{tabular}

Yume $^{a}=$ Yumenohatamochi, ${ }^{*}$ and ${ }^{* *}$ indicate significant at 5\% and 1\% level, respectively, by ANOVA. NS indicates not significant. 


\section{Transpiration}

The amounts of transpired water (Tr/VPD) of all the cultivars were significantly low in the dry treatment than those in the wet treatment at all growth stages (Table 5 ). In the wet treatment, there were no significant differences in Tr/VPD among the cultivars in the period from sowing to 40 days after. Japanese cultivars significantly transpired greater amount of water than NERICA cultivars from 40 days after sowing to booting stage due to their long vegetative growth. Between booting and 2 weeks after heading stages, the amount of transpired water of NERICA cultivars and Yumenohatamochi did not differ, while that of Hinohikari was significantly low. From 2 weeks after heading to maturity stages, the Tr/VPD of Yumenohatamochi was significantly lower than those of NERICA 1 and Hinohikari. In the dry treatment, no significant difference in the Tr/VPD was observed among the cultivars from sowing to 40 days after sowing. The Tr/VPD was significantly higher in Japanese cultivars than in NERICA cultivars from 40 days after sowing to booting stage. The Tr/VPD was significantly higher in the NERICA cultivars than in the Japanese cultivars from booting stage to 2 weeks after heading stage. From 2 weeks after heading to maturity stages, the $\mathrm{Tr} / \mathrm{VPD}$ was significantly lower in Yumenohatamochi than in the other cultivars.

Table 5 Weight of transpired water (Tr) of selected rice cultivars at different growth stages.

\begin{tabular}{|c|c|c|c|c|c|}
\hline \multirow[t]{2}{*}{$\begin{array}{l}\text { Water } \\
\text { regemes }(W)\end{array}$} & \multirow[t]{2}{*}{ Cultivars (C) } & \multicolumn{4}{|c|}{$\begin{array}{l}\text { Transpired water (Tr) /Vapor pressure deficit (VPD) } \\
\qquad\left(\operatorname{Kgpot}^{-1} \mathbf{k P a}^{-1}\right)\end{array}$} \\
\hline & & $\begin{array}{l}\text { Sowing } \\
-40 D A S\end{array}$ & $\begin{array}{l}\text { 40DAS } \\
\text {-Booting }\end{array}$ & $\begin{array}{l}\text { Booting- } \\
\text { 2WAH }\end{array}$ & $\begin{array}{l}\text { 2WAH- } \\
\text { Maturity }\end{array}$ \\
\hline \multirow[t]{4}{*}{ Wet $(80 \%)$} & NERICA1 & $1.21 \mathrm{a}$ & $6.56 c$ & 3.99a & $4.25 a$ \\
\hline & NERICA2 & $1.22 \mathrm{a}$ & $6.34 c$ & $4.09 a$ & $3.82 \mathrm{ab}$ \\
\hline & Yume $^{a}$ & $1.31 \mathrm{a}$ & $7.77 \mathrm{~b}$ & $3.98 a$ & $3.66 \mathrm{bc}$ \\
\hline & Hinohikari & $1.16 \mathrm{a}$ & $10.70 \mathrm{a}$ & $2.45 c$ & $4.25 \mathrm{a}$ \\
\hline \multirow[t]{4}{*}{ Dry (60\%) } & NERICA1 & $0.51 \mathrm{~b}$ & $3.92 \mathrm{~d}$ & $2.78 \mathrm{~b}$ & $3.25 c$ \\
\hline & NERICA2 & $0.53 b$ & $4.05 d$ & $2.85 b$ & $3.31 \mathrm{c}$ \\
\hline & Yume $^{a}$ & $0.57 b$ & $7.00 \mathrm{bc}$ & $1.74 \mathrm{~d}$ & $2.66 \mathrm{~d}$ \\
\hline & Hinohikari & $0.54 \mathrm{~b}$ & $6.19 c$ & $1.63 d$ & $3.74 \mathrm{abc}$ \\
\hline \multirow[t]{3}{*}{ ANOVA } & W & $* *$ & $* *$ & $* *$ & ** \\
\hline & $\mathrm{C}$ & NS & $* *$ & $* *$ & $* *$ \\
\hline & $\mathrm{W} \times \mathrm{C}$ & NS & $* *$ & $* *$ & $* *$ \\
\hline
\end{tabular}

Yume $^{a}=$ Yumenohatamochi, ${ }^{*}$ and ${ }^{* *}$ indicate significant at $5 \%$ and $1 \%$ level, respectively, by ANOVA. NS indicates not significant.

\section{Water use efficiency}

Water use efficiency of the tested cultivars presented using figure three (3) indicates a correlation between shoot dry weight and (transpired water/VPD) from sowing to booting and maturity. The slope is the increment of shoot dry weight per unit $\operatorname{Tr}$ /VPD, i.e., water use efficiency (WUE). Close correlations were found in all the cultivars indicating that there were no significant differences of water use efficiency among cultivars when the relationship was examined with plots from all the growth stages in both the wet and the dry treatments. It was unlikely that the slopes were 
different among the cultivars (Figure 2 ).

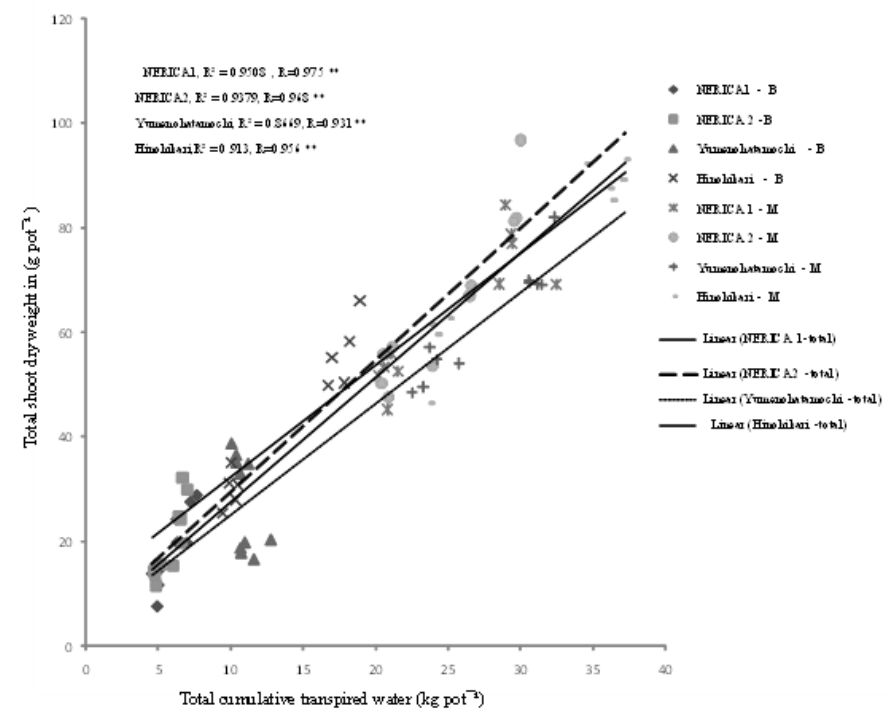

Figure 2 Shows the correlation between total water uptake andtotal shoot dry weight of four rice cultivars grown in pots under wet and drywater regimes at booting (B) and maturity(M) respectively (R2 and R) indicatessquare root of regression and regression values of the four cultivars tested.** Significant at $1 \%$, and $5 \%$ levels.

\section{Nitrogen concentration and total nitrogen contents in shoots}

Indicates the $\mathrm{N}$ concentration and total $\mathrm{N}$ content in shoots at booting and maturity stages. The soil drynessincereased the $\mathrm{N}$ concentration at the booting stage. At maturity the wet treatment had higher $\mathrm{N}$ concentration than the dry treatment. However, NERICA cultivars had the highest $\mathrm{N}$ concentrations than the Japanese cultivars at both booting and maturity stages regardless of water regime.

Total Nitrogen $(\mathrm{N})$ contents did not differ significantly among the rice cultivars at booting. However, the total $(\mathrm{N})$ in the dry treatment were lower than in the wet treatment at maturity stage. NERICA cultivars had apparently higher total $\mathrm{N}$ contents than those of the Japanese cultivar at maturity stage although NERICA 2 had higher $\mathrm{N}$ contents at booting and maturity stage than all the cultivars tested. The total $\mathrm{N}$ contents of NERICA 1 was at the same level as in Japanese cultivars at booting stage, and slightly became higher only than Hinohikari at maturity stage (Table 6 ).

Table 6 Shoot dry weight (SDWt), nitrogen concentration ( $\mathrm{N}$ conc. \%), and total nitrogen content (Total $\mathrm{N}$ ) at booting, and at maturity of NERICA's as compared to two Japanese rice cultivars grown in pots.

\begin{tabular}{|c|c|c|c|}
\hline $\begin{array}{c}\text { Water } \\
\text { regime } \\
\text { (W) }\end{array}$ & $\begin{array}{c}\text { Cultivars } \\
\text { (C) }\end{array}$ & Booting stages & Maturity stage (Harvest) \\
\hline
\end{tabular}

Continued on next page 


\begin{tabular}{|c|c|c|c|c|c|c|c|}
\hline \multicolumn{8}{|c|}{ Table 6 continued } \\
\hline & & $\begin{array}{l}\text { SDWt(g } \\
\left.\text { pot }^{-1}\right)\end{array}$ & $\begin{array}{c}\text { N Conc } \\
(\%)\end{array}$ & $\begin{array}{c}\text { Total } \\
\text { N(g } \\
\left.\text { pot }^{-1}\right)\end{array}$ & $\begin{array}{l}\text { SDWt(g } \\
\left.\text { pot }^{-1}\right)\end{array}$ & $\begin{array}{c}\text { N Conc } \\
(\%)\end{array}$ & $\begin{array}{c}\text { Total N (g } \\
\operatorname{pot}^{-1} \text { ) }\end{array}$ \\
\hline \multirow{4}{*}{$\begin{array}{c}\text { Wet } \\
(80 \%)\end{array}$} & NERICA1 & $24.1 \mathrm{~cd}$ & $2.05 \mathrm{c}$ & $0.26 \mathrm{ab}$ & $75.6 \mathrm{~b}$ & $2.23 \mathrm{bc}$ & $0.42 \mathrm{~b}$ \\
\hline & NERICA2 & $26.1 \mathrm{~cd}$ & $2.17 \mathrm{bc}$ & $0.29 \mathrm{a}$ & $79.1 \mathrm{ab}$ & $2.33 \mathrm{abc}$ & $0.52 \mathrm{a}$ \\
\hline & Yume $^{a}$ & $35.6 \mathrm{~b}$ & $1.62 \mathrm{~d}$ & $0.28 \mathrm{a}$ & $71.9 \mathrm{~b}$ & $1.88 \mathrm{~d}$ & $0.35 \mathrm{bc}$ \\
\hline & Hinohikari & 55.9 a & $1.00 \mathrm{e}$ & $0.27 \mathrm{ab}$ & $89.4 \mathrm{a}$ & $1.60 \mathrm{e}$ & $0.31 \mathrm{~cd}$ \\
\hline \multirow{7}{*}{$\begin{array}{c}\text { Dry } \\
(60 \%)\end{array}$} & NERICA1 & $11.9 \mathrm{e}$ & $2.47 \mathrm{ab}$ & $0.16 \mathrm{c}$ & $51.7 \mathrm{c}$ & $2.39 \mathrm{ab}$ & $0.26 \mathrm{de}$ \\
\hline & NERICA2 & $14.1 \mathrm{e}$ & $2.49 \mathrm{a}$ & $0.19 \mathrm{bc}$ & $52.9 \mathrm{c}$ & $2.48 \mathrm{a}$ & $0.32 \mathrm{~cd}$ \\
\hline & Yume $^{a}$ & $18.6 \mathrm{de}$ & $2.13 \mathrm{c}$ & $0.20 \mathrm{abc}$ & $52.8 \mathrm{c}$ & $2.17 \mathrm{c}$ & $0.24 \mathrm{de}$ \\
\hline & Hinohikari & $30.1 \mathrm{bc}$ & $1.42 \mathrm{~d}$ & $0.21 \mathrm{abc}$ & $56.7 \mathrm{c}$ & $1.75 \mathrm{de}$ & $0.22 \mathrm{e}$ \\
\hline & W & ** & $* *$ & ** & $* *$ & $* *$ & $* *$ \\
\hline & $\mathrm{C}$ & $* *$ & $* *$ & NS & $* *$ & $* *$ & $* *$ \\
\hline & W X C & $* *$ & NS & NS & NS & NS & $*$ \\
\hline
\end{tabular}

Yume $^{a}=$ Yumenohatamochi, ${ }^{*}$ and ${ }^{* *}$ indicate significant at $5 \%$ and $1 \%$ level, respectively, by ANOVA. NS indicates not significant.

\section{Relationship between total transpired water and total $\mathrm{N}$ uptake}

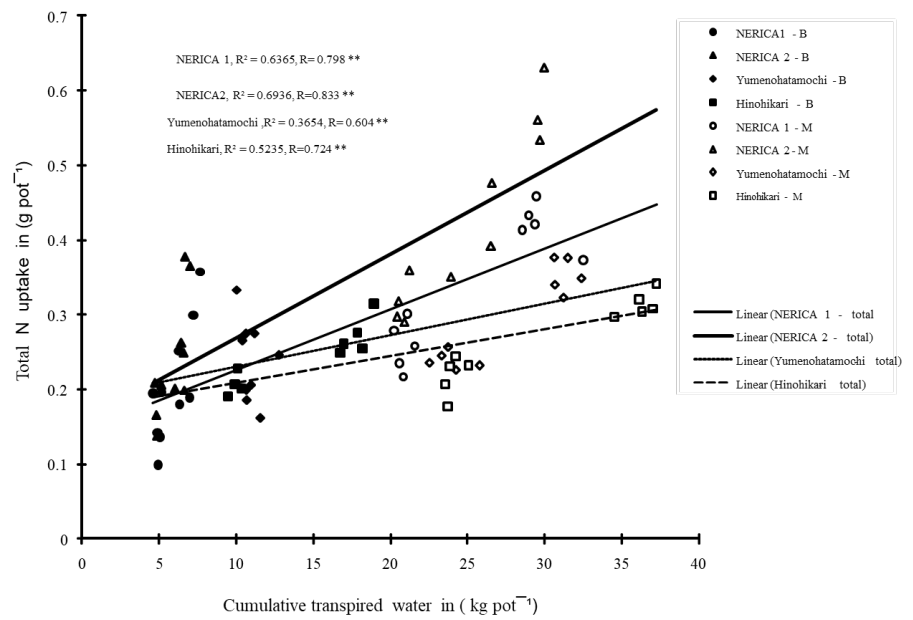

Figure 3 Shows the correlation between total water uptake and Total N uptake in four rice cultivars grown in pots under wet and dry water regimes at booting and maturity respectively, closed symbols indicate booting stages and open symbols indicates maturity stage. ( $\mathrm{R}^{2}$ and $\mathrm{R}$ ) indicates square root of regression and regression values of the four cultivars tested. ${ }^{* *}$ Significant at $1 \%$, and at $5 \%$ level

Figure 3 indicates a correlation between absolute weight of transpired water (Tr) from sowing to booting and maturity, and the total $\mathrm{N}$ content. When the relationship was examined with plots obtained from all the growth stages in the wet and the dry treatments (Figure $3 \mathrm{~A}$ ), the total $\mathrm{N}$ content was significantly correlated with the $\mathrm{Tr}$ in all the cultivars. In the wet treatment as shown in (Figure $3 \mathrm{~B}$ ), a significant relationship between $\mathrm{Tr}$ and the total $\mathrm{N}$ uptake were also found in all the cultivars. In the dry 
treatment (Figure $3 \mathrm{C}$ ), however, the relationship in Hinohikari was not significant at $\mathrm{P}<0.05$ level, while all the upland rice cultivars showed a significant correlation as found in the wet treatment.

\section{DISCUSSION}

\section{Characteristics in Transpiration and Water use efficiency of NERICA}

Short duration from sowing to heading stage of NERICA observed in the study was availing to save their water consumption in the vegetative stage this finding was also reported by (WARDA 2008). The heading stage of NERICA 1 and NERICA 2 in the wet treatment occurred 16-19 days and 26-29 days earlier than Yumenohatamochi and Hinohikari, respectively. The short duration to heading stage of NERICA cultivars restricted leaf area development and therefore lowered the Tr/VPD. However, rapid development of leaf area enlarged the Tr/VPD of NERICA cultivars after booting stage, particularly in the dry treatment. The high Tr/VPD of NERICA cultivars indicated that much carbon was assimilated in leaves during the period. Interestingly, during 2 weeks after heading to maturity stage, increase in the shoot dry weight of NERICA cultivars was higher than that of Japanese cultivars in wet treatment. However Japanese cultivars, ability of carbon assimilation likely degraded at the period, The high dry matter accumulation in grain filling stage of NERICA cultivars revealed by this study is in line with the findings reported by Matsunami et al. (2010) who found an increment of approximately $900-1000 \mathrm{~g} \mathrm{~m}^{-2}$ during grain filling period in shoot dry weight of NERICA, while the increase was only 600-700 g m-2 for Japanese Yumenohatamochi cultivar. They also reported that NERICA kept high level of transpiration rate in flag leaves after heading stages to maturity.

The present study also revealed that the Water use efficiency derived from the shoot dry weight and the Tr/VPD after sowing was comparable between NERICA cultivars and Japanese cultivars (Fig. 4). Thus, we conclude that NERICA 1 and 2 do not develop specific mechanisms to enhance the Water use efficiency the result of this study was in agreement to KOBATA et al. (1996) who investigated the WUE in field grown and pot-grown rice using cultivars differing in dry matter production under drought conditions. In those studies, close correlation between the shoot dry weight and the Tr/VPD were found, indicating there may not be genetic differences in WUE among rice cultivars.

\section{Nitrogen uptake remobilization during grain filling period}

The study found that NERICA2 had apparently higher total nitrogen (N) contents at early reproductive stage (booting) under water limited condition compared to other cultivars tested. During booting to maturity period or grain filling growth stage, the total $\mathrm{N}$ contents in NERICA cultivars increased significantly than the Japanese cultivars tested, these results were caused by increased transpiration rates during grain filling period in NERICA cultivars. The study revealed high correlation between transpired water and nitrogen $\mathrm{N}$ uptake in both wet and dry treatments. The findings are 
in line with those reported by O'Toole and Baldia (1982) who found that the transpiration and nutrient uptake are highly correlated during development of even mild soil and plant stress. Implying that higher transpiration rate enhance high Nitrogen uptake capacity. NERICA cultivars retained higher concentration of Nitrogen $(\mathrm{N})$ in stems and leaves than Japanese cultivars during grain filling stages, thus why the $\mathrm{N}$ content per pot was greater at maturity in NERICA compared to Japanese cultivars. Therefore, the high $\mathrm{N}$ concentration in shoots of NERICA cultivars would be involved in the high accumulation of dry matter during grain filling stages because NERICA 1 and NERICA 2 markedly increased the dry weight during two weeks after heading stage. The $\mathrm{N}$ concentration in NERICA 1 and NERICA 2 was almost two times higher than Yumenohatamochi and Hinohikari which showed no increase in the dry weight during 2 weeks after heading stage. These results were in agreement with those reported by Matsunami et al. (2010) reported that NERICA cultivars had higher increments of Nitrogen $(\mathrm{N})$ content during the ripening stage than Japanese cultivars in a rainfed upland condition regardless of Nitrogen fertilizer levels. Thus, it can be considered that the high $\mathrm{N}$ availability at the late grain filling stage allows NERICA cultivars to perform active photosynthesis during the periods.

\section{CONCLUSIONS AND RECOMMENDATIONS}

Water and $\mathrm{N}$ uptake in NERICA cultivars were apparently higher than in Japanese cultivars tested depending on growth stages, water regime and nitrogen level condition in soils. NERICA2 maintained higher water and nitrogen $\mathrm{N}$ uptake at later growth stages than NERICA1 though both NERICA cultivars showed slightly higher uptake capacity of water and nitrogen $\mathrm{N}$ compared to Japanese cultivars tested. High water uptake capacity in NERICAs was found to enhance higher nitrogen $\mathrm{N}$ uptake at later growth stages. Evaluated Water use efficiency as ratio of total shoot dry weights and (Tr/VPD) from sowing to maturity showed that NERICA cultivars were not significantly different from those in Japanese cultivars tested.

It was concluded that short growth duration in NERICAs, high water and N uptake capacities during grain filling period are accounted for their higher productivity in limited water and N-nutrition conditions. It was recommended further studies to analyze the morphological and physiological responses of roots in respects to water and nutrient stress in order to know the mechanism behind tolerance of NERICAs under soil drying moisture conditions.

\section{ACKNOWLEDGEMENTS}

The author gratefully acknowledges Prof. Tadashi Takahashi and Dr. Hideki Araki from the department of Crop Science Yamaguchi University for their constructive comments, and critical advices during the study period in Japan. Sincerely thanks to JICA Chogoku centre for sponsoring this study. 


\section{REFERENCES}

Consortium Formed To Rapidly Disseminate New Rice For Africa. (2000). Org/Warda1/Main/Newsrelease/Newsrel-Consortiumapr01.Htm.

KITILU, M. J. F., NYOMORA, A. M. S., \& CHARLES, J. (2019). Effects of moisture stresses during vegetative and reproductive growth phases on productivity of six selected rain-fed rice varieties in Ifakara, Tanzania. African Journal of Agricultural Research, 14(2), 5464. Retrieved from https://dx.doi.org/10.5897/ajar2018.10599 10.5897/ajar2018 10599

Kitilu, M. J. F., Nyomora, A. M. S., \& Charles, J. (2019). Moisture requirement and water productivity of selected rainfed rice varieties grown under controlled water environment in Ifakara, Tanzania. Journal of Cereals and Oilseeds, 10(1), 1-15. Retrieved from https://dx.doi.org/10.5897/jco2018.0188 10.5897/jco2018.0188

KOBATA, T., OKUNO, T., \& YAMAMOTO, T. (1996). Contributions of Capacity for Soil Water Extraction and Water Use Efficiency to Maintenance of Dry matter Production in Rice subjected to Drought. Japanese Journal of Crop Science, 65(4), 652-662. Retrieved from https://dx.doi.org/10.1626/jcs.65.652 10.1626/jcs.65.652

Matsunami, M., Matsunami, T., \& Kokubun, M. (2009). Growth and Yield of New Rice for Africa (NERICAs) under Different Ecosystems and Nitrogen Levels. Plant Production Science, 12(3), 381-389. Retrieved from https://dx.doi.org/10.1626/pps.12.381 10.1626/pps .12 .381

Matsunami, M., Matsunami, T., \& Kokubun, M. (2010). Comparison of Nitrogen Uptake, Transpiration Rate and Exudation Rate between Upland NERICAs and Japanese Cultivars. Plant Production Science, 13(4), 347-350. Retrieved from https://dx.doi.org/10.1626/ pps.13.347 10.1626/pps.13.347

National Rice Development Strategy. (2009). MAFC (Ministry Of Agriculture Food Security And Cooperatives).

NERICA; The New Rice For Africa- A Compendium. (2008). Africa Rice Center (WARDA), 2728.

Oikeh, S. O., Nwilene, F., Diatta, S., Osiname, O., Touré, A., \& Okeleye, K. A. (2008). Responses of Upland NERICA Rice to Nitrogen and Phosphorus in Forest Agroecosystems. Agronomy Journal, 100(3), AGJ2AGRONJ20070212-AGJ2AGRONJ20070212. Retrieved from https://dx.doi.org/10.2134/agronj2007.0212 10.2134/agronj2007.0212

O'Toole, J. C., \& Baldia, E. P. (1982). Water Deficits and Mineral Uptake in Rice 1. Crop Science, 22(6), 1144-1150. Retrieved from https://dx.doi.org/10.2135/cropsci1982 $.0011183 x 002200060014 x$ 10.2135/cropsci1982.0011183x002200060014x

The Rice Challenge In Africa. (2004). Http//Www.Warda.Org.

Rowhani, P., Lobell, D. B., Linderman, M., \& Ramankutty, N. (2011). Climate variability and crop production in Tanzania. Agricultural and Forest Meteorology, 151(4), 449460. Retrieved from https://dx.doi.org/10.1016/j.agrformet.2010.12.002 10.1016/ j.agrformet.2010.12.002

Sikuku, P. A., Onyango, J. C., \& Netondo, G. W. (2012). Yield Components And Gas Exchange Responses Of NERICA Rice Varieties (Oryza Sativa L.) To Vegetative And Reproductive Stage Water Deficit. Global Journal of Science Frontier Research (D), 12(3), 1-1.

Tahmasebi, Z., Pirdashti, H., S, S. A. M. M., \& Balouchi, H. (2008). Study of Water Stress Effects in Different Growth Stages on Yield and Yield Components of Different Rice (Oryza sativa L.) Cultivars. Pakistan Journal of Biological Sciences, 11(10), 1303-1309. Retrieved from https://dx.doi.org/10.3923/pjbs.2008.1303.1309 10.3923/pjbs.2008.1303.1309 